Cahiers $d u$ MONDE RUSSE

\section{Cahiers du monde russe}

Russie - Empire russe - Union soviétique et États indépendants

\title{
Zemstvo severnoi oblasti v epokhu rossiiskoi grazhdanskoi voiny
}

Mezhdu politicheskim predstavitel'stvom i upravlencheskoi biurokratiei Le zemstvo de la région (oblast') du Nord pendant la guerre civile : entre représentation politique et bureaucratie administrative The zemstvo of the Northern oblast' during the Civil War: Between political representation and administrative bureaucracy

\section{Liudmila Novikova}

\section{(2) OpenEdition}

\section{Journals}

Édition électronique

URL : http://journals.openedition.org/monderusse/10071

DOI : 10.4000/monderusse. 10071

ISSN : $1777-5388$

Éditeur

Éditions de l'EHESS

Édition imprimée

Date de publication : 1 janvier 2017

Pagination : $95-122$

ISBN : 978-2-7132-2696-0

ISSN : $1252-6576$

\section{Référence électronique}

Liudmila Novikova, "Zemstvo severnoi oblasti v epokhu rossiiskoi grazhdanskoi voiny », Cahiers du monde russe [Онлайн], 58/1-2 | 2017, Выложить онлайн 01 janvier 2019, Наводить справки в 10 décembre 2020. URL : http://journals.openedition.org/monderusse/10071 ; DOI : https://doi.org/ 10.4000/monderusse.10071 


\title{
ZEMSTVO SEVERNOI OBLASTI V EPOKHU ROSSIISKOI GRAZHDANSKOI VOINY
}

\author{
Mezhdu politicheskim predstavitel'stvom \\ i upravlencheskoi biurokratiei ${ }^{1}$
}

[Le zemstvo de la région du Nord pendant la guerre civile : entre représentation politique et bureaucratie administrative]

Выборное земское самоуправление, существовавшее с 1864 г. по период гражданской войны, многим современникам казалось важным инструментом социальной и политической интеграции российского общества. На заре земской истории представители либеральной общественности и даже правительственные бюрократы приветствовали в лице земств появление механизма, способного наладить решение местных проблем на местах и преодолеть разрыв между крестьянами и политическими и культурными элитами. Самоуправления виделись школой политического воспитания, «которая в общине образует гражданина для государства», которая воспитывает «через любовь и преданность ближайшим кругам истинный патриотизм», и без которой жители империи обратятся в «обезличенные и бессвязные толпы населения», в «людскую пыль» ${ }^{2}$.

1. [Людмила Новикова, «Земство Северной области в эпоху российской гражданской войны: между политическим представительством и управленческой бюрократией»]. Исследование финансировалось в рамках государственной поддержки ведущих университетов Российской Федерации «5-100».

2. А.Д. Градовский, «Начала русского государственного права», в А.Д. Градовский, Собрание сочинений, т. 9 (СПб.: Типография М.М. Стасюлевича, 1908), 14; С.Ю. Витте, Самодержавие и земство: Конфиденциальная записка Министра финансов Статссекретаря С.Ю. Витmе (1899 г.), 2-е изд., (Stuttgart: Verlag und Druck von J.H.W. Dietz Nachf., 1903), 7. 
В некоторой мере земства, как отмечается в недавней историографии, действительно содействовали социальной и политической модернизации российского общества. Земские служащие, например, агрономы и учителя прививали крестьянам новые практические навыки и идеи и, тем самым, способствовали преодолению культурного разрыва между массами и общественными элитами ${ }^{3}$. А в годы Первой мировой войны они содействовали распространению представлений о российской нации, объединявшей все общественные группы и вместе противостоявшей врагу ${ }^{4}$.

Но все же многие исследователи сходятся во мнении, что, несмотря на определенные успехи, земства не были достаточно эффективны и не пользовались популярностью у населения. Так, крестьяне жаловались на тяжесть земских налогов и нередко считали земства чуждыми, помещичьими учреждениями, так как из-за куриальной системы выборов в земствах преобладали дворяне. Земскую систему раскалывали не только социальные, но и национальные противоречия: например, в западных губерниях с преобладающим нерусским населением земства были введены с запозданием, а особая выборная система там давала преимущество русским и православным ${ }^{5}$. В итоге, как механизм земских выборов, так и состав земских собраний и управ часто не столько сглаживали противоречия, сколько подчеркивали линии социального и национального раскола. Попытка реформировать земскую систему после Февральской революции 1917 г. не смогла укрепить репутацию земств ${ }^{6}$ В итоге, крах земского самоуправления, последовавший за Октябрем 1917 г., нередко рассматривается как закономерный финал в истории этого института, встреченный с чувством радости и облегчения значительной частью избирателей ${ }^{7}$.

3. Н.Г. Королева, ред., Земское самоуправление в России, 1864-1918, в 2 кн. (М.: Наука, 2005), кн. 1, 294-420; кн. 2, 47-236; Ilya V. Gerasimov, Modernism and Public Reform in Late Imperial Russia: Rural Professionals and Self-Organization, 1905-1930 (New York: Palgrave Macmillan, 2009).

4. См., например: Scott J. Serengy, «Zemstvo, Peasants, and Citizenship: The Russian Adult Education Movement and World War I», Slavic Review, 59, 2 (2000): 290-315.

5. О земствах в Западном крае см.: А.Я. Аврех, «Вопрос о западном земстве и банкротство Столыпина», Исторические записки, 70 (1961): 61-112; Geoffrey A. Hosking, The Russian Constitutional Experiment: Government and Duma, 1907-1914 (Cambridge: Cambridge University Press, 1973), 116-140; М. Долбилов, А. Миллер, ред., Западные окраинь Российской империи (М.: Новое литературное обозрение, 2006), 378-381.

6. Кимитака Мацузато, «Почему умерли земства», Родина, № 7 (1994): 38-40.

7. О взглядах крестьян на земство см.: Dorothy Atkinson, «The Zemstvo and the Peasantry» in Terence Emmons and Wayne S. Vucinich, eds., The Zemstvo in Russia: An Experiment in Local Self-Government (Cambridge: Cambridge University Press, 1982), 110-125; Sergei Liubichankovskii, «Revolution and the Creation of the Volost' Zemstvo in South-Eastern Russia (Spring-Fall 1917)», in Sarah Badcock, Liudmila Novikova, and Aaron Retish, eds., Russia's Home Front in War and Revolution 1914-1922, book 1, Russia's Revolution in Regional Perspective (Bloomington, IN: Slavica Publishers, 2015), 45-66; Stephen A. Smith, "Citizenship and the Russian Nation during World War I," Slavic Review, 59, 2 (2000): 324, 328. 
Именно на 1917-1918 гг. большинство исследователей ставят точку в истории земства ${ }^{8}$. Однако эта точка была, скорее, многоточием. После краткого перерыва в своей деятельности земства возродились в годы гражданской войны на территории, подконтрольной белым правительствам, и продолжали существовать до подавления последних антибольшевистских анклавов. Для возрожденных земств, действовавших в обширных областях страны с 1918 по 1920 гг., не были характерны многие недостатки позднеимперской системы самоуправления. В новых земствах, как например, на Севере России и в Сибири, не преобладали дворяне, так как сословные и имущественные ограничения на выборах были отменены, и так как помещичье землевладение вообще не было распространено на занимаемой белыми имперской периферии. Земства, введенные на северных и восточных окраинах страны только в 1917 г., воспринимались как наследие революции, а не как пережиток старого режима. Население более не тяготили и земские налоги, так как в гражданскую войну значительная часть земских расходов покрывалась субсидиями от казны. Наконец, как показывает пример Севера России, земства эпохи гражданской войны претендовали на то, чтобы стать основой гражданского управления. Теперь это было уже не пресловутое ленинское «пятое колесо в телеге русского государственного управления» (фраза была заимствована Владимиром Лениным у Михаила Салтыкова-Щедрина ${ }^{9}$ ), а многоэтажное здание самоуправлений, увенчать которое в будущем должно было Национальное или Учредительное собрание. Иными словами, «белые» земства времен гражданской войны, и прежде всего, земства Северной области, казалось, были в большей мере приспособлены к тому, чтобы стать действенным механизмом низового политического представительства и общественной интеграции.

Данная статья рассматривает, насколько северным земствам в годы гражданской войны действительно удалось сыграть представительную и интегрирующую роль. Я исследую земства на материале антибольшевистской Северной области, которая занимала обширную территорию Архангельской губернии, протянувшуюся от финской границы до предгорий Урала. В отдельные периоды область охватывала также соседние уезды Вологодской и Олонецкой губерний. Появившись вследствие антибольшевистского переворота в Архангельске 2 августа 1918 г., Северная область просуществовала до февраля 1920 г. В течение всего этого периода в ней действовали земские учреждения.

8. См., например: Королева, ред., Земское самоуправление в России, 1864-1918; John M. Corcoran, Power in the Provinces: The Evolution of the Local Government Practice in Imperial Russia, 1825-1917 (Ph.D. dissertation; Georgetown University, 2012).

9. В.И. Ленин, «Гонители земства и аннибалы либерализма», в В.И. Ленин, Полное собрание сочинений, т. 5 (М.: Издательство политической литературы, 1959), 35. 


\section{Земства Архангельской губернии}

Архангельские земства заметно отличались от «традиционных» земств центра страны. Учрежденные, как и сибирские земства, только в 1917 г. по решению революционного Временного правительства, они выделялись и демократичностью своего состава, и той ведущей ролью, которую получили представители социалистических партий в руководстве выборными земскими органами. Хотя в своей практической деятельности северные земства старались ориентироваться на опыт прежних земских учреждений и на выработанные теми «особые методы и приемы в земской работе» ${ }^{10}$, весь их политический облик отражал особые революционные обстоятельства их появления.

Северные земства эпохи гражданской войны отличались не только «революционным» происхождением, но и благоприятными условиями, в которых им довелось действовать. Если земская работа на белом Юге России и в Сибири была отмечена частыми конфликтами между земцами и военными властями, а также резким сокращением сферы земских полномочий, то в Архангельске, напротив, власти в целом благоприятствовали деятельности земств $^{11}$. При Северном правительстве, которое вначале лично, а потом после своего отъезда в Париж в январе 1919 г. — уже формально возглавлял народный социалист Николай Чайковский, земства даже расширили сферу своей деятельности по сравнению с той, что была у земств не только до революции, но и в 1917 г. В частности, земские представители участвовали в выработке земельного законодательства Северного правительства, в обсуждении реформ образовательной системы; в отдельные периоды выборные земские представители входили в кабинет.

Хотя главным фактором, повлиявшим на особое положение земств в Северной области, была поддержка земского самоуправления со стороны главы правительства - старого революционера Чайковского, а также со стороны влиятельных представителей социалистических партий на местах, у земств имелся и более широкий круг союзников. На Севере даже многие либеральные политики и военные деятели, включая генералгубернатора области Евгения Миллера, признавали, что земскую работу необходимо поддерживать «по политическим соображениям» ${ }^{12}$. Они

10. ГААО (Государственный архив Архангельской области), ф. 1865, Архангельская губернская земская управа, оп. 1, д. 4, Протокол № 1 первой чрезычайной сессии Архангельского губернского земского собрания, 14 декаря 1917 г., л. 5.

11. Краткий обзор деятельности земств при белых правительствах см.: William G. Rosenberg, «The Zemstvo in 1917 and its Fate under Bolshevik Rule», in Emmons and Vucinich, eds., The Zemstvo in Russia, 410-413. О земствах на Юге России и в Сибири см.: Peter Kenez, Civil War in South Russia, 1919-1920: The Defeat of the Whites (Berkeley: University of California Press, 1977), 60; Jonathan D. Smele, Civil War in Siberia: The Anti-Bolshevik Government of Admiral Kolchak, 1918-1920 (Cambridge: Cambridge University Press, 1996), 263-274.

12. ГАРФ (Государственный архив Российской федерации), ф. 16, Канцелярия Временного правительства Северной области, оп. 1, Журналы заседаний, д. 4, Журнал заседания Временного правительства Северной области, 18 января 1919 г., л. 73-73об. 
опасались, что наступление на права земств будет непопулярно у населения и ослабит позиции белой власти. Но, поддержав земства, они, в то же время, пытались встроить их в систему власти и поставить их аппарат на службу обороне области.

Несмотря на то, что судьба северных земств отличалась от положения земств на других белых территориях, их пример позволяет с нового ракурса взглянуть на вопрос о роли местного управления в годы гражданской войны. С одной стороны, их опыт подчеркивает разнообразие политических и административных институтов, действовавших в России в революционный период. С другой стороны, на примере достаточно успешной деятельности северного земства ярче видны возможности, но также и пределы развития земского представительства в годы гражданской войны.

В целом, земства Северной области были сравнительно эффективны и популярны у населения. Однако их представительная политическая функция оказалась резко ограничена из-за подчинения земств правительственному контролю. Существуя в условиях острейшего военного и политического кризиса, земства на «белой» территории превратились в выборную часть государственной администрации, стали инструментом правительства, которое использовало земства для достижения собственных политических и военных целей. Резкое огосударствление земств не было неожиданным: оно началось в старых земских губерниях уже в годы Первой мировой войны и в период власти Временного правительства, когда земства стали, говоря словами Питера Холквиста, частью «пара-государственного комплекса», целью которого была мобилизация экономики и общества на войну ${ }^{13}$. Кризис гражданской войны еще более усилил эту тенденцию. Более того, в период гражданской войны централизация местных органов власти была более общим феноменом и происходила по обе стороны фронта: подчинение северных земств белой власти зеркально отражало процессы, происходившие по красную сторону фронта, где местные советы утратили свою автономию и стали звеньями единого партийно-советского аппарата.

Подчинение северных земств белой власти и очевидные параллели между развитием земств и советов в период гражданской войны пока не получили отражения в историографии. Например, немногочисленные работы об архангельском земстве того периода, напротив, часто делали акцент на имевших место конфликтах между земскими социалистами и консервативными белыми кругами. Историки подчеркивали оппозиционность ряда земских лидеров Северному правительству. Указывая на критику власти со стороны земств, они видели в ней попытку реализовать демократическую «среднюю линию» - между коммунистическим режимом и белыми генеральскими диктатурами. Авторы подчеркивали, что в конечном итоге, эта попытка оказалась 
безуспешной - точно так же, как и земские усилия по улучшению положения населения и укреплению своего авторитета ${ }^{14}$.

Приведенный здесь материал позволяет оспорить и уточнить эти утверждения. Земства, которые не были лишены поддержки со стороны населения Архангельской губернии, порой выступали с критикой отдельных аспектов белой политики. Однако в условиях непримиримого военного противостояния, они все больше превращались в опору белого правительства на местах, в инструмент его политической власти. Далее я рассмотрю развитие северных земств в годы гражданской войны с трех перспектив: с перспективы населения области, участвовавшего в земских выборах и пытавшегося при помощи земства решить свои хозяйственные проблемы и внутридеревенские конфликты; с перспективы Северного белого правительства, желавшего использовать земства как рычаг собственного влияния на местах; и с перспективы лидеров губернского земства - раздираемых между стремлениями восстановить российское государство, демократизировать белую политику, воспитать население в ценностях демократии и государственности, и вытребовать из казны финансирование для обширных земских программ.

В итоге, несмотря на попытки северных земцев сохранить политическую самостоятельность органов земского самоуправления, обстоятельства гражданской войны вынуждали земства все более и более полагаться на политическую поддержку и финансовую помощь со стороны казны. Если в целом, как отмечается в политологической литературе, местное самоуправление как институт, всегда и везде, занимает двойственное положение между представительством местных интересов, с одной стороны, и выполнением государственных функций - с другой ${ }^{15}$, то очевидно, гражданская война стала поворотным пунктом в истории земств. Так, даже в Северной области, где земства пользовались наиболее значительным влиянием, баланс резко сместился в сторону централизации органов местной власти и усиления над ними государственного контроля.

\section{Земства северной области и крестьянство}

2 августа 1918 г. обыватели провинциального Архангельска, затаив дыхание, следили за быстрой сменой политических кулис. Они могли наблюдать за бегством большевистского губернского исполкома, перестрелками на улицах

14. См.: В.В. Осипов, Земства Европейского Севера России в 1917-1920 г2. На материалах Архангельской и Вологодской губерний (Автореферат диссертации к.и.н., Архангельск, 2000); П.В. Федоров, Земства и советы Архангельской губернии в 1917-1920 г2. (Автореферат диссертации к.и.н., Мурманск, 2001); А.В. Воронин, П.В. Федоров, Власть и самоуправление: Архангельская губерния в период револючии (1917-1920) (Мурманск: Тип. «Заполярный труд», 2002).

15. См., например: Edward C. Page, Localism and Centralism in Europe: The Political and Legal Bases of Local Self-Government (Oxford: Oxford University Press, 1991), 1-3. 
между отступавшими красноармейцами и крестьянскими и офицерскими отрядами, и, наконец, стать свидетелями торжественной высадки на набережной Северной Двины вооруженного отряда Антанты, пришедшего на помощь повстанцам ${ }^{16}$. На следующее утро расклеенные по городу листовки объяснили смысл произошедшего. В них говорилось, что советская власть в губернии пала, что в Архангельске образовано Верховное управление Северной области, включавшее членов разогнанного в начале 1918 г. Учредительного собрания, что в области восстанавливаются демократические права и свободы и что новое правительство намерено при содействии других антибольшевистских правительств, а также бывших союзников России по Первой мировой войне, а именно Англии, Франции и США, воссоздать «единую всероссийскую государственную власть». По всей территории Северной области восстанавливались земства как «органы истинного народовластия», которые вместе с уездными и губернскими правительственными комиссарами должны были составить основу местного управления ${ }^{17}$. В сферу компетенции земств передавалось народное образование, социальное обеспечение, распределение продовольствия, а также управление землями и лесами, находившимися в пользовании населения, и функции низшей судебной инстанции ${ }^{18}$.

Решение Северного правительства о восстановлении земств было смелым политическим ходом, так как предшествующая история земского самоуправления в Архангельской губернии была короткой и неуспешной. В отличие от центральных губерний страны, где земства насчитывали пятидесятилетнюю историю своей деятельности, северные земства имели за плечами лишь несколько месяцев работы. Они впервые были учреждены в губернии постановлением всероссийского Временного правительства от 17 июня 1917 г. «О введении земских учреждений в губернии Архангельской и губерниях и областях Сибири». После недолгого организационного периода осенью 1917 г. на Севере прошли местные земские выборы, совпавшие по времени с выборами в Учредительное собрание. Однако когда в декабре 1917 г. губернское земское собрание открыло свое первое заседание, власть в стране уже находилась в руках большевиков. После нескольких месяцев политической неопределенности, сопровождавшейся укреплением власти

16. О перевороте в Архангельске и его предыстории см.: Л.Г. Новикова, Провинциальная «контрреволюиия»: Белое движение и Гражданская война на русском Севере, 1917-1920 (М.: Новое литературное обозрение, 2011), 71-81.

17. См.: Собрание узаконений и распоряжений Верховного управления и Временного правительства Северной области [далее - ВУ и ВПСО], № 1 (1918): 6-7, 8-11. В Северной области восстанавливалось действие земских положений Временного правительства 1917 г. с незначительными изменениями, см.: Собрание узаконений и распоряжений ВУ и ВПСО, № 1 (1918), Ст. 114.

18. O сфере компетенций земств см.: Р. Koptiakoff, «The Zemstvo in North Russia», in Union of Russian Zemstvos and Towns (London Committee). North-Russian Zemsvos and Municipalities. Statements by the Congress of Zemstvo and Municipalities of North Russia and by the North-Russian Municipal and Zemstvo Delegation to the Peoples of the Allied Countries (London: Union of Russian Zemstvos and Towns, 1919), 15-22. 
губернского совета и большевистского влияния в местных органах власти, весной 1918 г. архангельские земства были упразднены и передали свои хозяйственные функции советам ${ }^{19}$.

Однако в августе 1918 г. пришедшее к власти в Архангельске антибольшевистское правительство решило вновь восстановить земства и передать в их руки власть на местах. Возвращение к земскому самоуправлению основывалось одновременно на практических и на идейных соображениях. Если Северное правительство хотело быстро наладить аппарат местного управления, то кроме земств, ему не на что больше было опереться. Власть местных советов оно признать не могло из-за классового принципа их формирования и из-за того, что в уездных центрах и некоторых волостях ими руководили большевики. Выборные же члены земских собраний и управ, лишь недавно отстраненные от работы, часто находились на месте и вновь были готовы взяться за дело. Выбор в пользу земства диктовался и идейными причинами. Верховное управление Северной области, объединившее в своих рядах политических деятелей от эсеров и меньшевиков до кадетов, выдвигало широкую демократическую программу, рассчитывая в политическом отношении повернуть часы назад к Февралю 1917 г. Северное земство идеально подходило на роль низового звена в системе демократического управления. Земские самоуправления были организованы на всех уровнях — от волости до губернии — и избраны всеобщим и равным голосованием. Поэтому северное правительство могло рассчитывать на то, что восстановление всенародно избранных в период революции и преимущественно крестьянских по составу земств встретит сочувствие и поддержку среди местного населения.

Впрочем, с точки зрения обывателей Архангельской губернии, возвращение земств означало не восстановление наиболее популярных органов низового представительства, а продолжение пореволюционной административной чехарды. Это была уже третья по счету смена местной власти за прошедший год, последовавшая за прежним учреждением земств, а затем преобразованием их в советы. Поэтому распоряжение правительства о восстановлении земств в ряде уездов и волостей было первоначально воспринято с недоумением, а иногда даже и враждебностью. Так, если в уездных центрах, включая Холмогоры, Мезень, Пинегу, и сам Архангельск, уездные земские управы возобновили свою работу в течение нескольких дней после антибольшевистского переворота, в некоторых других городах и селах население первоначально не посчитало нужным ликвидировать советы. Вместо этого были организованы перевыборы советов, или же из их состава были изгнаны наиболее непопулярные большевистские лидеры, а сами советы продолжили свою работу. Например, в Онеге 10 августа собрался 6-й уездный съезд крестьянских депутатов, который хотя и поддержал Северное правительство,

19. См.: Воронин, Федоров, Власть и самоуправление; М.В. Шумилов, Октябрьская револющия на Севере России (Петрозаводск: Изд-во «Карелия», 1973), 160-164, 183-187, 215-216. 
но избрал Онежский народный совет как главный орган власти в уезде. ${ }^{20}$ В Печорском уезде в связи со сменой власти в крае был созван чрезвычайный съезд советов. Он выразил поддержку правительству, но в качестве органа местной власти избрал временный комитет, в который очевидно вошли многие бывшие члены исполкома совета ${ }^{21}$.

Подобная путаница в местной администрации продолжалась несколько месяцев. Однако уже к концу осени 1918 г. земства практически повсеместно утвердились как основные органы самоуправления в губернии. Это было связано, с одной стороны, с тем, что Северное правительство категорически отказывалось признавать советы и комитеты в качестве органов местной власти. С другой же стороны, местное население, поняв, что у Архангельска часто не было возможности контролировать состав самоуправлений, нередко просто преобразовывало в земства другие органы власти, имевшиеся на местах. Многие, вероятно, рассуждали так же, как делегат Онежского уездного съезда Драгунов, заявивший на съезде:

Наша задача - создать такую власть, которая базировалась бы на всеобщем, прямом, равном и тайном голосовании, а как эта власть будет называться: Советами или Земством - не важно. ${ }^{22}$

В итоге, не умея предугадать, сколько времени продержится у власти белое правительство, и сколько проработают учреждаемые им земства, жители губернии после некоторых колебаний согласились с восстановлением земств, но попытались одновременно поставить их на службу собственным интересам.

Переход к земскому управлению произошел в обширной Архангельской губернии уже к октябрю-ноябрю 1918 г., когда в большинстве волостей и уездов вместо советов начали действовать временные земские собрания и управы. Видимый успех правительства был отчасти связан с тем, что оно первоначально не имело возможности предотвратить простого переименования действовавших на местах выборных комитетов и советов в земства. Например, собрание рыбаков становища Териберка на Мурманском побережье, получив строгое указание избрать новое местное самоуправление, постановило «в местную земскую управу выбрать совет рыбачьих

20. ГАРФ, ф. 3695, Отдел внутренних дел Временного правительства Северной области, оп. 1, д. 72, Письмо Онежского уездного комитета Верховному управлению, 10 августа 1918 г., л. 34.

21. ГАРФ, ф. 16, оп. 1, д. 64, телеграмма Рогачева, представителя Печорского временного правительственного комитета, 15 августа 1918 г., л. 25.

22. ГААО, ф. 1865 , оп. 1, д. 148, Протокол 6-го Онежского крестьянского съезда, 11 августа 1918 г., л. 5. Более подробно о хаосе в местном управлении и трудностях перехода к земскому самоуправлению в Северной области летом-осенью 1918 г. см.: Liudmila G. Novikova, «Northerners into Whites: Popular Participation in the Counter-Revolution in Arkhangel'sk Province, Summer-Autumn 1918,» Europe-Asia Studies, 60, 2 (March 2008): 283-286. 
депутатов» ${ }^{23}$. В городе Коле местный совет не стал даже формально переизбираться и лишь поменял название на временное земство. Председатель совета в телеграмме в Архангельск оправдывал это решение тем, что прежняя земская управа, избранная в 1917 г., не могла быть созвана, так как многих ее членов не было на месте, в то время как полномочия совета «не выходили за пределы прежней управы» ${ }^{24}$. Онежский совет также вскоре после своего избрания переименовался в земский комитет. Во многих волостях перемена ознаменовалась снятием красного флага и помещением вывески «земство» на здании прежнего совета. Архангельское правительство, не имея возможности близко контролировать положение на местах, обычно признавало полномочия таких земств ${ }^{25}$.

В последующие недели Архангельск предпринимал эпизодические попытки бороться с «засильем» прежних советских лидеров в новообразованных органах самоуправления. Однако эти усилия не были систематическими. В первую очередь, они были направлены на участников наиболее влиятельных органов бывшей советской администрации, как например Мурманского краевого совета. Хотя члены совета поддержали белый переворот и признали власть Северного правительства, длительная история сотрудничества совета с большевистским правительством в Москве сделала его неприемлемым для консервативных кругов Северной области и белого офицерства. В итоге, не только совет был официально распущен, но и многие его члены оказались под арестом².

Случай с арестом членов Мурманского совета, вызвавший недоумение в социалистических кругах области, впрочем, не отражал более широкого положения дел в местной администрации. На протяжении всего существования Северной области в земствах продолжали работать многие члены и руководители прежних советов. Причем это было характерно и для волостных и уездных самоуправлений, и для губернского земства. Например, Алексей Иванов, один из лидеров архангельской организации эсеров, возглавлявший в 1917 г. губернский Совет крестьянских депутатов, и сотрудничавший в Архангельском губернском земстве, после августа 1918 г. возглавлял сессии губернских земских собраний и даже дважды входил в состав Северного

23. ГАМО (Государственный архив Мурманской области), ф. П-102, Истпарткомиссия при Мурманском окружном комитете ВКП(б), оп. 1, д. 16, Воспоминания Компилова, 1939 г., л. 30.

24. ГАРФ, ф. 3695, оп. 1., д. 3, Телеграфная переписка председателя Кольского совета Лоушкина и заведующего Отделом внутренних дел П.Ю. Зубова, 29-30 августа 1918 г., л. $42-43,45$.

25. См., например: ГАРФ, ф. 3811, Фонд начальника Архангельской губернии, оп. 1 , д. 2, Протоколы заседаний губернского правительственного комитета, 15 и 22 августа, 3 сентября 1918 г., л. 23, 29, 42; д. 142, Донесение комиссара Шенкурского уезда А.Е. Исупова, 5 октября 1918 г., л. 102-103.

26. Об этом подробнее см.: Yanni Kotsonis, «Arkhangel'sk, 1918: Regionalism and Populism in the Russian Civil War», Russian Review, 51, 4 (Oct. 1992): 538-540. 
правительства как представитель местных социалистических кругов ${ }^{27}$. На местном уровне, например, председатель земской управы Лисестровской волости меньшевик Гордей Мосеев, имевший за плечами опыт советского работника и сделавший карьеру в войсковых комитетах и советах солдатских депутатов в 1917 г., с приходом белых получил мандат в волостное земство и председательство в земской управе ${ }^{28}$.

Появление Иванова и Мосеева во главе северных земств подчеркивает, что в местной белой администрации продолжали работать умеренные социалисты, в прошлом сотрудничавшие в советах. Выступив против большевистского «переворота» в Петрограде, они теперь поддержали Северное правительство и связали с ним надежды на создание демократической власти в стране и созыв Учредительного собрания. Также, тесная связь между прежними советами и земствами обеспечила земствам поддержку среди населения губернии. Жители северной окраины после некоторых колебаний поддержали восстановление земств, если в составе земских собраний и управ они видели прежних авторитетных местных представителей. Восстановление земств открывало для населения возможность коммуникации с новой властью при посредничестве земских лидеров, полномочия которых были признаны и местными жителями, и властью. Таким образом, земства возобновили свою работу не потому, что крестьяне считали их предпочтительной формой управления по сравнению с советами. А потому, что при белой власти земства оказались единственными действенными органами управления на местах. Именно эта их практическая значимость обеспечила земствам сочувствие со стороны населения.

Поддержку земств со стороны крестьян отразили, в частности, результаты земских перевыборов, организованных Северным правительством осенью 1918 - весной 1919 г. Несмотря на имевшие место нарушения и даже отказы от участия в выборах, в большинстве своем крестьяне отнеслись к ним со всей серьезностью. Даже близость линии фронта, плохие пути сообщения и занятость населения на отхожих промыслах не помешали большинству жителей губернии принять участие в голосовании. Явка на выборы разнилась от $45 \%$ в прифронтовом Холмогорском уезде до 67\% тыловом Архангельском уезде ${ }^{29}$, и соответствовала уровню участия крестьян в первых земских выборах 1917 г. Она также была близка к показателям явки крестьян губернии на выборы в Учредительное собрание, когда число голосовавших составило около $67 \%{ }^{30}$.

27. Л.Г. Протасов, Люди Учредительного собрания: портреть в интерьере эпохи (М.: Росспэн, 2008), 301-302.

28. АРУ ФСБ АО (Архив регионального управления Федеральной службы безопасности по Архангельской области), д. П-16049, Следственное дело Г.Т. Мосеева.

29. Отчеты о выборах в земство см.: Вестник Временного правительства Северной области, 1919, 11, 14, 22 и 25 января, 1 и 20 февраля, 5 и 17 марта, 4, 5, 9, 29 апреля, 6 и 17 мая.

30. Об участии крестьян Архангельской губернии в земских выборах 1917 г. и в выборах в Учредительное собрание см.: Воронин, Федоров, Власть и самоуправление, 73; Л.Г. Протасов, Всероссийское Учредительное собрание: история рождения и гибели (М.: Росспэн, 1997), 197. 
Судя по этим показателям, северные крестьяне верили в практическую значимость земств и доверяли земству не меньше (или не значительно меньше) чем Учредительному собранию, и участвовали в земских выборах настолько же активно, как и в 1917 году.

Таким образом, после Октября 1917 г. земская система не была полностью и безнадежно дискредитирована, как порой утверждается в историографии. Пример Северной области показывает, что в условиях, когда земства оказывались единственной действенной формой местного управления, признаваемой властью, крестьяне вполне прагматически поддерживали их работу. Вместе с тем, они пытались ввести в их состав авторитетных местных представителей, а также привлечь их для защиты собственных экономических интересов и для разрешения внутридеревенских конфликтов.

\section{Земства как общественный форум}

В Северной области земские собрания и совещания нередко становились форумами для выявления местных нужд и выторговывания помощи и уступок от областного руководства. Именно по такому сценарию 15 февраля 1919 г. прошло совещание членов Онежской уездной земской управы, председателей волостных управ и чинов городского самоуправления в присутствии управляющего правительственным Отделом внутренних дел Владимира Игнатьева, приехавшего обсудить вопрос о мобилизации в белую армию. На совещании член уездной земской управы Крысанов говорил об острой нехватке продовольствия и об отсутствии семян и настаивал на том, чтобы правительство увеличило нормированный продовольственный паек до 30 фунтов хлеба на человека в месяц и организовало доставку семян. Представитель города Онеги Гусев сетовал на массовую безработицу в связи с закрытием лесопилок и полагал, что областная казна должна профинансировать общественные работы по осушке болот и проведению дорог или взять на свое содержание лесозаводы. Делегаты от волостей просили увеличить продовольственный паек и прислать в волости фельдшеров и лекарства. Итоговая резолюция с перечислением всех нужд была отправлена вместе с Игнатьевым в Архангельск ${ }^{31}$. В других случаях на уездных собраниях представители волостей также перечисляли нужды населения и просили о выделении средств, а общее голосование переадресовывало эти запросы областному правительству $^{32}$. Даже на губернское земское собрание в Архангельске делегаты уездов

31. ГААО, ф. 1865 , оп. 1 , д. 633 , Протокол собрания представителей земств и городского самоуправления Онежского уезда, 15 февраля 1919 г., л. 7об.-11.

32. См.: ГААО, ф. 1865 , оп. 1, д. 633, Протокол Архангельского уездного земского собрания, 17 марта 1919 г., л. 218-222. См. также сообщение об Онежском уездном земском собрании: Вестник Временного правительства Северной области, 1919, 1 апреля. 
приезжали, прихватив с собой расходные сметы земских бюджетов и резолюции с просьбами о помощи населению ${ }^{33}$.

Эти просьбы не были пустой риторикой. Так как на нехлебородный север продовольствие поступало в значительной степени от бывших стран-союзниц России по Антанте ${ }^{34}$, активное лоббирование земцами местных интересов, например, влияло на распределение продуктов по волостям и могло заметно улучшить положение населения.

В годы гражданской войны земства являлись не только форумом для выявления нужд населения и торга с областной властью, но также они служили посредниками между различными группами интересов в самой деревне. В частности, в Северной области земства выступали в роли третейского судьи в поземельных конфликтах, занимаясь к тому же распределением среди крестьян дополнительных наделов из фонда государственных земель. Несмотря на то, что на Севере помещичье землевладение отсутствовало, и в целом сельское хозяйство играло в экономике второстепенную роль ${ }^{35}$, Революция 1917 г. обострила поземельные споры среди самих крестьян и соседских общин ${ }^{36}$. После того как в сентябре 1918 г. Северное правительство официально передало в распоряжение земств управление землями, находившимися в пользовании крестьян ${ }^{37}$, именно земства стали главным регулятором местного землепользования, отвечая на многочисленные крестьянские обращения. Более того, земские представители активно участвовали и в разработке аграрного законодательства Северной области в рамках работы специальной комиссии при Отделе земледелия. Их лозунг «Земля — тому, кто ее обрабатывает» - лег в основу правительственных законов, принятых в начале 1919 г. - наиболее радикальных из всех земельных законов белых правительств ${ }^{38}$.

Северные земства, впервые обретя необходимые ресурсы и определенные властные полномочия, не ограничивались разрешением продовольственных и земельных вопросов. Они предпринимали практические шаги в области

33. ГААО, ф. 1865 , оп. 1, д. 152, Протокол Архангельского губернского земского собрания, 12 сентября 1918 г., л. 14об.-19.

34. Об объемах союзных поставок см.: Kenneth Bourne and D. Cameron Watt, eds., British Documents on Foreign Affairs: Reports and Papers from the Foreign Office Confidential Print, part II, series A, vol. 1 (Frederick, Md.: University Publications of America, 1984), 164-169.

35. Об экономике Севера до 1917 г. см.: Ю.А. Поляков, История Северного крестьянства в период капитализма (Архангельск: Сев.-Зап. кн. изд-во, 1985).

36. Об аграрной революции на Севере см.: А.В. Саблин, Аграрная революция на Европейском Севере России, 1917-1921 (Социальные и экономические результаты) (Вологда: Легия, 2002).

37. Собрание узаконений и распоряжений ВУСО, № 1 (1918), 6-7; статьи 82, 115.

38. Собрание узаконений и распоряжений Временного правительства Северной области, № 6 (1919), ст. 279; № 9 (1919), ст. 361; № 12 (1919), ст. 398. Об участии земства в выработке аграрных постановлений и регулировании земельных споров см.: Union of Russian Zemstvos and Towns (London Committee). North-Russian Zemstvos and Municipalities, Statements by the Congress of Zemstvo and Municipalities of North Russia, 18-20. 
развития агрономии, медицины, образования. Например, в годы гражданской войны северные земства открыли несколько агрономических станций и попытались организовать поставки в область семян и сельскохозяйственного оборудования из-за границы ${ }^{39}$. Реагируя на распространение эпидемий и отсутствие медицинской помощи на селе, земства содействовали открытию новых фельдшерских пунктов и созданию врачебных эпидемических отрядов, которые отправлялись в местности, охваченные массовыми заболеваниями ${ }^{40}$. Особенно большие усилия земства направляли на развитие системы образования, выделяя на эти цели более четверти всего земского бюджета. Несмотря на военный кризис, в Архангельской губернии были открыты к началу 1920 г. 23 новых низших начальных училища, несколько гимназий и ремесленных училищ. Большое внимание земства уделяли развитию внешкольного образования: в области были открыты новые вечерние и воскресные школы для взрослых, клубы и читальни. Эти шаги, в частности открытие новых школ, также встречали сочувствие и содействие со стороны крестьян. Так, крестьянские кооперативы по собственной инициативе широко помогали земствам ремонтировать школьные здания и клубы ${ }^{41}$.

В целом, быстрое восстановление земств после августа 1918 г., активное участие населения в земских перевыборах и деятельность земств по распределению продовольствия и разрешению земельных споров, а также их шаги в области развития образования, свидетельствуют об относительной успешности и популярности северных земств. Крестьяне из вполне прагматических соображений поддерживали земства и часто обращались к их помощи для разрешения насущных местных проблем ${ }^{42}$. Тем не менее, гражданская война радикально изменила положение земств в системе государственной власти: она усилила централизацию земского аппарата, превратив земства, в первую очередь, в местных агентов власти белого правительства и сделав их частью его мобилизационных властных структур.

39. Вестник Временного правительства Северной области, 1919, 12 января, 5 апреля. О поставках сельскохозяйственных машин см. переписку с Отделом иностранных дел правительства, июль 1919 г.: ГАРФ, ф. 17, Отдел иностранных дел Временного правительства Северной области, оп. 1, д. 62, л. 5, 18.

40. Вестник Временного правительства Северной области, 1919, 23 января; 6 и 15 марта.

41. Union of Russian Zemstvos and Towns (London Committee). North-Russian Zemstvos and Municipalities, Statements by the Congress of Zemstvo and Municipalities of North Russia, 17; Воронин, Федоров, Власть и самоуправление, 153; Новикова, Провинииальная «контрреволюция», 168.

42. Более подробно о взаимоотношениях крестьян с земствами в Северной области см.: Liudmila G. Novikova, «Zemstvo, State and Peasants in Arkhangel'sk province, 1917-1920», in Badcock, Novikova, and Retish, eds., Russia's Home Front in War and Revolution 1914-1922, book 1, Russia's Revolution in Regional Perspective, 87-108. 


\section{Земства в политике Северного правительства}

В отличие от крестьян, руководители Северного правительства придавали земствам не столько местное практическое, сколько более обширное политическое и даже идеологическое значение. С точки зрения белой власти, главная задача земств в период гражданской войны заключалась не в выявлении нужд населения и не в улаживании деревенских споров, а в том, чтобы способствовать воссозданию единого российского государства. Руководители области видели в земствах политический и административный орган, который должен был стоять на страже государственных интересов, содействовать военной мобилизации людей и ресурсов, и, работая с населением, восстанавливать государственность «снизу».

Как говорил глава правительства Чайковский 11 августа 1918 г. на совещании членов правительства с представителями земств, городских дум, комитетов политических партий и профсоюзов, важнейшей целью выборных самоуправлений было помочь народу «оздороветь от большевистского безумия». Радикализм русской революции Чайковский объяснял тем, что «у молодого в политической жизни народа не было опыта». Поэтому

когда пало самодержавие, народ, сбросив оковы гнета, по чувству решил, что он все может, и вот все видят, что народ попал в пропасть, где нет государственности, и где человек человеку враг.

Земства должны были помочь в преодолении этого кризиса, став «фундаментом строения жизни». Проводя параллели с опытом Земгора - Союзом земств и городов, содействовавшим мобилизации экономики в годы Первой мировой войны, глава кабинета считал, что местные самоуправления и в хозяйственном отношении «лучше всего в состоянии быть приноровленными к обстоятельствам военного времени» ${ }^{43}$. Мысли о неопытности народа, у которого «голова закружилась» от безграничных «горизонтов революции», Чайковский повторял и позже, в частности в сентябре 1918 г. на открытии Архангельского губернского собрания. Там он также ругал большевиков, развивших политическую борьбу до таких пределов, что «национальные устои, национальные скрепы не выдержали»; и выражал надежду на скорое «отрезвление» народных масс при содействии земств, чем будет заложен «основной камень общерусского дела» ${ }^{44}$.

В целом, Чайковский симпатизировал земствам и полагал, что в идеальных обстоятельствах опека государства над ними должна быть минимальной. Он утверждал, что «[г]осударственная власть - лишь контролирующий

43. Вестник Верховного управления Северной области, 1918, 13 и 14 августа.

44. ГААО, ф. 1865 , оп. 1, д. 152, Протокол Архангельского губернского земского собрания, 11 сентября 1918 г., л. 5-6. 
аппарат, прислушивающийся к начинаниям и запросам народных масс» ${ }^{45}$. В то же время, следуя Чайковскому, в обстоятельствах гражданской войны значение и роль государства существенно возрастали; и соответственно менялась и функция земств. Если население еще не полностью «оздоровело» от большевизма и не понимало истинной ценности государственных форм бытия, то земства не должны были во всем следовать за своими избирателями. Напротив, главной задачей земств в тех условиях было ограничивать запросы масс и воспитывать народ так, чтобы он понял задачи государства и действовал в его интересах.

Подчеркнутое внимание Чайковского к государственной - воспитательной и административной - функции земств не было исключительно реакцией на особые обстоятельства гражданской войны. Отчасти эти идеи о сути земского представительства присутствовали уже в позднеимперской России. Если первоначально, в момент введения земств в 1860-1870-е гг., следуя господствовавшей в то время «общественной теории» самоуправления, земства признавались учреждениями не государственными, а общественными, действовавшими в рамках особого общественного права; то уже в 1880-е гг. на смену пришла «государственная» теория, следуя которой не существовало обособленных местных задач. Все дела признавались государственными и лишь переданными государством в руки органов самоуправления, способных с большим знанием обстановки работать в интересах государства ${ }^{46}$. Во многом повторяя изменения, происходившие в правовых теориях и практиках самоуправления в Западной Европе, российские земства уже до революции постепенно сближались с государственным административным аппаратом ${ }^{47}$.

Особенно остро вопрос о государственной роли земств встал в кризисный период революции и гражданской войны. Вследствие реформ Временного правительства 1917 г. земства должны были стать основой местной администрации и все более превращались в агентов правительственной власти на

45. Вестник Верховного управления Северной области, 1918, 13 и 14 августа.

46. П.П. Гронский, «Теории самоуправления в русской науке», в кн. Б.Б. Веселовский и З.Г. Френкель, ред., Юбилейный земский сборник, 1864-1914 (СПб.: Издание т-ва О.Н. Поповой, 1914), 77-85; Н.Н. Авинов, «Главные черты в истории законодательства о земских учреждениях (1864-1913 гг.)», в Юбилейный земский сборник, 2-9; Frederick S. Starr, Decentralization and Self-Government in Russia, 1830-1870 (Princeton: Princeton University Press, 1972), 241-288.

47. Гронский, «Теории самоуправления в русской науке», 76-77; Т. Свиридова, «Гражданская идентичность и местное (земское) самоуправление в XIX в. в России и в Западной Европе», в Б. Пиетров-Эннкер и Г.Н. Ульянова, ред., Гражданская идентичность и сфера гражданской деятельности в Российской империи. Вторая половина ХІХ-начало $X X$ века (М.: Росспэн, 2007), 124-152. Об изменениях в европейском самоуправлении в XIX в. см.: Page, Localism and Centralism in Europe, 118-125. О бюрократизации земств см.: К. Мацузато, А. Ярцев, В. Абрамов, Земский феномен: политологический подход (Саппоро: Slavic Research Center, 2001), 88-95. 
местах $^{48}$. В годы гражданской войны их связь с государственным аппаратом усилилась еще более.

\section{Земства, этатизм и борьба с сепаратистскими движениями}

Представление о необходимости подчинить земства интересам правительственной власти было связано с усилением этатистских идей в период революции и гражданской войны. Этатизм уже в 1917 г. буквально пропитал российский политический дискурс, будучи реакцией на возросшую внешнюю угрозу и на прогрессирующий развал государственной власти. В обстановке последовавшей гражданской войны представители всех политических партий, поддержавших антибольшевистские правительства, были даже готовы отказаться от части своих главных принципов ради спасения российского государства. Как показал Уильям Розенберг, кадеты, для которых еще до мировой войны были характерны «широкий национализм» и почитание российской государственности, в 1917 г. и в период гражданской войны ради воссоздания сильного единого государства были готовы даже поддержать генеральские диктатуры, хотя это и резко расходилось с либеральными принципами ${ }^{49}$. Лидеры народных социалистов также пришли к выводу, что только при помощи государства можно было преодолеть национальный, классовый и региональный разлад и обуздать крестьянскую анархию. Не отвергая в принципе идей социализма, они полагали, что социалистические преобразования должны подождать до воссоздания единой государственности ${ }^{50}$. На левом флаге - эсеры также, по словам Оливера Рэдки, уже в 1917 г. в большинстве своем совершили поворот к национализму и этатизму ${ }^{51}$. Хотя в годы гражданской войны они использовали риторику «класса» для объяснения происходящих событий, особое значение для них приобретает «язык национализма» ${ }^{52}$. Подобные этатистские представления определяли политику Северного правительства в отношении земств и в тот период, когда Чайковский стоял во главе кабинета, и позже, когда с отъездом Чайковского на мирную конференцию в Париж в январе 1919 г. ведущую политическую роль начал играть генерал-губернатор Северной области Евгений Миллер.

48. Rosenberg, «The zemstvo in 1917 and its fate under Bolshevik rule»; Г.А. Герасименко, Земское самоуправление в России (М.: Наука, 1990).

49. William G. Rosenberg, Liberals in the Russian Revolution: The Constitutional Democratic Party, 1917-1921 (Princeton: Princeton University Press, 1974).

50. Jason R. Antevil, The Politics of Russian Populism, 1894-1929: V.A. Miakotin, A.V. Peshekhonov, and the Popular Socialist Party, 2 vols. (Ph.D. dissertation, Stanford University, 1998).

51. Oliver Radkey, The Agrarian Foes of Bolshevism: Promise and Default of the Russian Socialist Revolutionaries, February to October 1917 (New York: Columbia University Press, 1958).

52. Scott B. Smith, Captives of Revolution: The Socialist Revolutionaries and the Bolshevik Dictatorship, 1918-1923 (Pittsburgh: University of Pittsburgh Press, 2011). 
Так как первоочередной задачей земств считалось участие в воссоздании российской государственности, местные самоуправления, по убеждению членов Северного правительства, должны были демонстративно поддерживать даже потенциально непопулярные решения кабинета, если эти решения были необходимы для успеха антибольшевистской борьбы. Это касалось, в частности, мобилизации в белую армию, попыток бороться с национальным сепаратизмом, а также продолжения обороны области в неблагоприятных военных и политических условиях.

Например, хотя мобилизация в белую армию традиционно не входила в полномочия земств, в этом вопросе Северное правительство опасалось действовать без опоры на выборные самоуправления. После того как революция привела к распаду имперской армии, попытки провести мобилизацию в красные и белые формирования часто наталкивались на недовольство и даже вооруженное сопротивление призывников. Поэтому когда осенью-зимой 1918 г. Северное правительство встало перед необходимостью начать массовые мобилизации, оно решило заручиться формальным одобрением земств.

Подобно тому, как большевики добивались соответствующих резолюций местных съездов советов при проведении первых мобилизаций, ${ }^{53}$ также и антибольшевистские руководители пытались опереться на поддержку уездных самоуправлений. Например, глава Отдела внутренних дел Игнатьев приехал в Онегу 15 февраля 1919 г. именно с целью заручиться согласием земцев на предстоящий призыв в армию в уезде. После его выступления собравшиеся члены Онежской уездной и волостных земских управ и чины городского самоуправления заявили о поддержке мобилизации и утвердили обращение к населению, призвав всех вступать в ряды армии в целях «возрождения Единой свободной России». Однако одновременно они обратились к правительству с просьбой об оказании материальной помощи уезду ${ }^{54}$. Правительство привлекало земства и к другим задачам, связанным с обороной области: земские самоуправления организовывали гужевую перевозку военных грузов и частей, занимались расквартированием войск, помощью беженцам, ремонтом дорог и мостов. Земства получали крупные субсидии из казны на оплату этих работ ${ }^{55}$.

Участвуя в мобилизации населения и ресурсов Северной области на войну против большевиков, северные земства также активно поддерживали

53. Например, см. резолюцию о мобилизации в Красную армию в Архангельской губернии, утвержденную Вторым губернским съездом советов 2 июля 1918 г.: Октябрьская револючия и гражданская война на Севере, вып. 1 (Архангельск: Партийное изд-во, 1933), 6; М.С. Кедров, За Советский Север: Личные воспоминания и материалы о первых этапах гражданской войны 1918 г. (Л.: Прибой, 1927), 42.

54. Вестник Временного правительства Северной области, 1919, 20 февраля.

55. О выделении субсидий земствам на оплату расходов, связанных с обороной области см., например: ГАРФ, ф. 16, Канцелярия Временного правительства Северной области, оп. 1, д. 9, Постановления ВПСО, 1919 г. 
Северное правительство в борьбе с национальным сепаратизмом. В частности они резко осудили претензии на независимость со стороны карельских волостей Кемского уезда. К концу 1918 г. власть Северного правительства над карельскими волостями была номинальной, что было следствием регулярных походов финских вооруженных отрядов в приграничные карельские волости с территории соседней Финляндии, развития карельского национального движения, а также элементарной неспособности белого правительства подчинить своей власти удаленный участок губернии с плохими путями коммуникаций. Тем не менее, Архангельск попытался организовать в этих волостях земские перевыборы и распространить на них воинскую повинность. Результат оказался неутешительным: прошедшие в феврале 1919 г. земские перевыборы в Кемском уезде были отмечены самой низкой явкой избирателей по области - всего 43\%. Причем даже эта явка была обеспечена преимущественно за счет русских волостей уезда. В некоторых приграничных карельских районах выборы вообще не проводились. Зато тогда же в Кеми на совещании представителей карельских волостей был образован Карельский национальный комитет, заявивший, что в будущем Карелия должна стать независимой страной ${ }^{56}$.

Чтобы исправить положение и вернуть себе влияние в Карелии, Северное правительство попыталось сильнее опереться на поддержку земств. Так, 13 апреля 1919 г. на первую сессию вновь избранного Кемского уездного земского собрания явился помощник генерал-губернатора по управлению Мурманским краем Василий Ермолов. После его гневной речи о карельском сепаратизме делегаты приняли решительную резолюцию. Они осудили создание национального комитета, назвав это действиями

незначительной группы безответственных лиц, которые прикрылись личиной демократизма, стремятся ввести в заблуждение [...] население Карелии.

Они заявили, что требования карельской самостоятельности не считаются «ни с желанием, ни с исторической правдой населения русского Поморья, Заонежья и Лапландии». Они утверждали, что

времена бесправия, произвола и насилия прошли навсегда, и упоминание о русском засилии, русском угнетении карельской национальности и

56. M. Jääskeläinen, Die ostkarelische Frage: Die Entstehung eines nationalen Expansionsprogramms und die Versuche zu seiner Verwirklichung in der Aussenpolitik Finnlands in den Jahren 1918-1920 (Helsinki: Finnischen Historischen Gesellschaft, 1965); Е.Ю. Дубровская, «Общественная жизнь карельского населения Олонецкой и Архангельской губерний в годы российской революции и гражданской войны (1917-1920)», в Г.Н. Севостьянов, ред., Трагедия великой державы: Наџиональный вопрос и распад Советского Союза (М.: Социально-политическая мысль, 2005), 136-152; Марина Витухновская-Кауппала, «“Карелия для карел!”: Гражданская война как катализатор национального самосознания», Ab Imperio, № 4 (2010): 245-282; Вестник Временного правительства Северной области, 1919, 9 апреля. 
культуры являются лишь негодными средствами для разрушения вековых братских уз.

И в заключение они призвали всех к борьбе за воссоздание «единой, великой, демократической России», в которой смогли бы свободно развиваться большие и малые национальности ${ }^{57}$. Впрочем, хотя земские представители и выразили полную поддержку централистским установкам белого руководства, эта поддержка не принесла успеха белой политике в карельском вопросе. Вплоть до конца существования Северной области Архангельск не сумел вернуть карельские волости под свой контроль ${ }^{58}$.

Несмотря на то, что поддержка земств не всегда оказывалась эффективной, Северное правительство продолжало предпринимать настойчивые попытки опереться на авторитет земств при решении ключевых политических вопросов и, в особенности, в периоды политических и военных кризисов. Наиболее ярким примером был созыв в августе 1919 г. Земско-городского совещания с целью демонстрации массовой поддержки власти. В тот момент - после неудачи летнего наступления на соединение с сибирскими войсками адмирала Александра Колчака и объявления стран Антанты о скором выводе с Севера союзных отрядов - положение северного белого фронта действительно казалось критическим. Прежде чем решиться на долгую осадную зиму, пережить которую предстояло без внешней поддержки и даже без возможности провести успешную эвакуацию войск по замерзшему Белому морю, белое руководство решило созвать представителей земских и городских самоуправлений и обсудить вопрос о целесообразности дальнейшей обороны. Целью властей было заручиться одобрением тотальной мобилизации населения и ресурсов области на войну. Хотя в зале совещания, открывшего свою работу 12 августа, преобладал критический настрой, и хотя его члены выдвинули правительству обвинения в недемократичности и в чрезмерном применении репрессий, в итоге, совещание всецело поддержало продолжение борьбы. Делегаты согласились на преобразование кабинета с участием земских представителей и выпустили воззвание к населению с призывом сражаться с большевиками под руководством «правительства обороны», облеченного народным доверием ${ }^{59}$. Многие члены самоуправлений сами отправились на фронт, чтобы влиться в ряды защитников области.

57. Резолюцию собрания см.: Вестник Временного правительства Северной области, 1919, 17 мая. Сообщение Ермолова о заседании см.: Там же, 22 апреля.

58. Е.Ю. Дубровская, «Из истории подготовки Ухтинского съезда представителей карельских волостей», в Вопросы истории Европейского Севера (Проблемы сочиальной экономики и политики: 60-е годы XIX-XX вв.) (Петрозаводск: Петрозаводский гос. ун-т, 1995), 67; ГАРФ, ф. 5867, Общество северян по собиранию и изданию материалов о Гражданской войне на Севере России, оп. 1, д. 26, Рапорт генерала Н.А. Клюева о поездке в Карелию, 3 июня 1920 г., л. 3-4.

59. ГААО, ф.50, Архангельская городская управа, оп. 5, д. 1, Материалы Земскогородского совещания. 
Похожая история повторилась еще раз в феврале 1920 г. - в последний месяц существования Северной области. Тогда, реагируя на стихийный распад фронта, правительство вновь попыталось опереться на авторитет Архангельского губернского земского собрания. И точно так же после резкой критики правительственного курса, земцы согласились на реорганизацию кабинета с участием представителей «общественности» и обратились к армии с призывом держать оборону ${ }^{60}$.

Хотя на этот раз земская поддержка уже не смогла спасти Северную область, очевидно, что вплоть до последних дней своего существования правительство пыталось использовать земства как опору в собственной политике. Несмотря на то, что члены губернского земского собрания и управы, порой, критиковали кабинет, белое руководство продолжало видеть в земских самоуправлениях своих агентов и союзников в восстановлении государственного порядка. На протяжении всего существования Северной области белое правительство использовало земства не столько для того, чтобы дать возможность населению выражать свои интересы и нужды, а сколько для того, чтобы укрепить оборону и мотивировать население на борьбу против большевиков, требуя от него еще большего физического напряжения и материальных жертв.

\section{Земские выборные представители в системе белой власти}

В ситуации, когда крестьяне Северной области стремились использовать земства в собственных интересах, а белое руководство пыталось сделать самоуправления частью государственного механизма по мобилизации населения и ресурсов региона на войну, у членов земских собраний и управ не было легкого выбора. Они считали, что как выборные представители населения они должны отстаивать его интересы в отношениях с властью. Более того, со временем многие земцы-социалисты стали критически относиться к усилению влияния генерала Миллера, обвиняя его в расширении репрессий и считая, что при нем политика кабинета шла вразрез с запросами масс. Однако в конечном итоге, земцы не только не противодействовали, но и сами способствовали сращиванию земств с государственным аппаратом и подчинению их правительственному контролю. Причинами этого был страх земцев перед народной «анархией», практически полная зависимость земских самоуправлений от казны в финансовом отношении, и наконец, осознание того, что победа большевиков в гражданской войне неизбежно положит конец самому существованию земств. В итоге, несмотря на недовольство отдельными аспектами белой политики, земцы приняли на себя роль низового звена в правительственном мобилизационном аппарате, отказавшись от автономии земств в пользу борьбы против общего врага.

60. ГАРФ, ф. 5867, оп. 1, д. 25, Протоколы и резолюции заседаний Архангельского губернского земского собрания, 5-7 февраля 1920 г., л. 70-71, 82-87 об. 
Уже на первых земских собраниях, восстановивших работу после прихода к власти Северного правительства, земские лидеры вторили Чайковскому, утверждая, что запросы населения должны быть ограничены нуждами государства и потребностями военного времени. Так, в сентябре 1918 г. на сессии Архангельского губернского земского собрания его первый председатель эсер Пётр Коптяков говорил о торжестве «идеи народоправства, идеи широкого участия всех слоев населения в устроении местной жизни и в строительстве общегосударственном». Но в то же время, он предостерегал, что нельзя во всем следовать народным требованиям:

[К]ак бурная река, выступающая из своих берегов, может [...] уничтожить ценности, созданные упорным человеческим трудом, - так и могучее народное движение, не введенное вовремя в берега законности, [...] в состоянии произвести разрушения, гибельные для всего государственного организма.

Поэтому важнейшей задачей земства было «напрячь все силы к пробуждению национального чувства» среди населения ${ }^{61}$. «Воспитание сознательных граждан» называли в качестве главной цели земств и другие делегаты, выступавшие на губернском земском собрании ${ }^{62}$. Даже в материалах уездных управ земства превозносились как главнейшее препятствие, «которое сдерживает натиски привыкших к разнузданности людей, блюдет и водворяет порядок, проповедует любовь к России, родине и государству и призывает к жертвам во имя этих идеалов» ${ }^{63}$. В последующие недели и месяцы новые земские собрания, открывавшие работу после перевыборов, неизменно слали правительству телеграммы, выражая стремление помочь ему в восстановлении «порядка» на местах и в воссоздании страны ${ }^{64}$.

Земские приветствия правительству отражали политическую и идейную близость многих земских деятелей с членами антибольшевистского кабинета. Подобно тому, как глава правительства Чайковский под влиянием первой мировой войны и революции превратился из революционера в государственника, также и многие члены архангельского губернского и уездных земских самоуправлений, среди которых было значительное число представителей небольшевистских социалистических партий и сельской интеллигенции, пришли к осознанию первенства общегосударственных интересов. Остро переживая заключение «позорного» мира с Германией, разгон Учредительного

61. ГААО, ф. 1865, оп. 1, д. 152, Протокол Архангельского губернского земского собрания, 11 сентября 1918 г., л. 1об.-2, 4об.

62. Там же, л. 8 об.

63. См. обращение Архангельской уездной земской управы к правительству: Вестник Временного правительства Северной области, 1919, 26 февраля.

64. См. телеграммы Архангельскому правительству от имени Мезенского, Онежского и Пинежского уездных собраний: Вестник Временного правительства Северной области, 1919, 23 марта; 25 марта; 15 апреля. 
собрания и распад страны, последовавший за приходом большевиков к власти, многие земские руководители поддержали антибольшевистский переворот и Северное правительство. Будущее страны они связывали с разгромом большевиков, а это требовало, в свою очередь, поддержки белой власти и армии. Поэтому не только идейные причины, но и сама логика противостояния с большевиками, подталкивали их к союзу с областной властью.

Спустя несколько месяцев после образования Северной области лозунги об укреплении порядка и государственной власти дополнились критикой текущей политики белого кабинета. Уже с весны-лета 1919 г. губернские земские гласные и члены управы - вслед за социалистическими делегатами из Архангельской городской думы и из руководства северных профсоюзов - начали выражать недовольство тем, что после отъезда Чайковского генерал Миллер сосредотачивал в своих руках все большие полномочия. Возмущались они и расширением политических арестов, направленных как на членов большевистского подполья в области, так и на многих недовольных режимом. Наиболее резко критика земских представителей в адрес кабинета прозвучала на Земско-городском совещании в августе 1919 г. и на внеочередной сессии Архангельского губернского земского собрания в феврале 1920 г. Делегаты говорили о необходимости в текущих условиях отстаивать «права человека и гражданина», и ограничить «произвол» военных властей ${ }^{65}$.

Впрочем, значение этих «оппозиционных» выступлений, на которые обращалось особое внимание в историографии, не следует переоценивать. Прежде всего, решительность земской «оппозиции» всегда оставалась довольно ограниченной. Каждый раз, когда внутренняя нестабильность или красное наступление угрожали устойчивости северного фронта, земцы откладывали в сторону свои политические претензии к власти, и призывами к населению и личным примером пытались укрепить оборону. Более того, даже критикуя власть от лица жителей области, они продолжали критиковать само население за неспособность понять суть политического момента и за чрезмерно утилитарный подход к деятельности самих земских самоуправлений. Так, председатель Архангельской губернской земской управы и резкий критик Северного правительства эсер Павел Скоморохов признавал, говоря об отношении к земствам, что «трудно сказать, с чьей стороны было больше непонимания - со стороны населения или со стороны власти» ${ }^{66}$. Более того, земцы даже в финансовом отношении не могли рассчитывать на поддержку со стороны населения и связывали расширение земской деятельности с увеличением правительственных субсидий.

65. ГААО, ф. 1865, оп. 1, д. 1242, Протокол 5-й чрезвычайной сессии Архангельского губернского земского собрания, 3 февраля 1920 г., л. 2-2об., 5-5об.

66. Там же, л. 4. 


\section{Земские финансы}

Финансирование работы земств преимущественно из средств областного бюджета отчасти было обусловлено самой структурой земских налогов. Предметом земского обложения традиционно были, в первую очередь, земли и недвижимость ${ }^{67}$. И на Севере с его обширными государственными лесными владениями казна неизбежно становилась значимым плательщиком земских налогов. Примечательно, что еще до революции во многом на государственные средства работали земства соседних северных губерний, где важнейшим источником земского налогообложения являлись казенные леса. Кроме того, в дореволюционной России в целом наблюдался рост доли центрального финансирования в земских бюджетах ${ }^{68}$. В годы же революции, хозяйственный развал еще более усилил зависимость земств от государственного бюджета. В итоге, в Северной области государственная поддержка земств достигла непомерных масштабов: из средств областного бюджета покрывалось около $90 \%$ земских расходов ${ }^{69}$.

В Архангельской губернии и правительство, и сами земцы пытались изыскать дополнительные источники земских доходов, чтобы поддержать земские программы и ослабить нагрузку на областной бюджет. Но введенные новые налоги в пользу земств - с оборота кооперативных товаров, с лесоматериалов и даже $\mathrm{c}$ пароходных билетов ${ }^{70}$, существенным образом ситуацию не изменили. Возможность же увеличения прямых налогов с населения в пользу земств была отвергнута сразу: и земские гласные, и члены правительства были уверены, что усиление сборов с разоренного населения только подорвет авторитет земств, а вместе с ними и белого правительства. В результате, земства вплоть до распада белого фронта продолжали работать за счет казенных субсидий. Земский бюджет, составленный губернской земской управой, утверждался на заседаниях кабинета. Кабинет корректировал земские расходы и, по сути, направлял работу земств ${ }^{71}$.

Центральное финансирование земской деятельности не только усилило правительственный контроль над земствами, но и способствовало централизации всей земской системы. Так, оно укрепило позиции губернского земства

67. В.Ф. Караваев, «Земские сметы и раскладки (Исторический очерк развития земских бюджетов)», в Юбилейный земский сборник, 155-179.

68. В среднем к 1914 г. земские самоуправления получали $20 \%$ и более денежных поступлений в виде пособий от казны. См.: Караваев, «Земские сметы и раскладки», 176-177; Tikhon J. Polner, Russian Local Government during the War and the Union of Zemstvos (New Haven: Yale University Press, 1930), 34; Королева, ред., Земское самоуправление в России, 1864-1918, кн. 2, 119.

69. ГАРФ, ф. 16, оп. 1, д. 4, Журнал заседания ВПСО, 18 января 1919 г., л. 73.

70. См. журналы заседаний и постановления ВПСО об определении новых источников земского налогообложения, 10 июля и 7 августа 1919 г.: ГАРФ, ф. 16, оп. 1, д. 12, л. 37-37об., 60-63, 154; д. 24, л. 80-80 об.

71. См., например детальное обсуждение кабинетом земского бюджета на 1919 г.: ГАРФ, ф. 16, оп. 1, д. 4, Журнал заседаний ВПСО, 18 января 1919 г., л. 73-75. 
за счет уездных и волостных земств: последние, по сути, превратились в подчиненные исполнительные органы ${ }^{72}$. Как весной 1919 г. жаловался от имени уездных гласных Коптяков, занимавший в тот период место председателя Архангельской уездной управы:

Неприветливо встретило губернское земство своего младшего товарища! [...] вследствие тяжелого финансового кризиса, постигшего край и особенно в силу того, что уездные земства явились лишь с расходными сметами и с громадными дефицитами в приходных [...] губернское собрание совершенно отринуло принцип автономности уездных земств и встало на путь централизации. ${ }^{73}$

Губернская земская управа самостоятельно принимала решения о дальнейшем перераспределении казенных субсидий, и соответственно - о масштабах и направлениях работы местных земств. В итоге, централизованная система земского финансирования упрочила власть правительства над губернским земством, но также и власть губернского земства - над уездными, и уездных — над волостными. Как в перевернутом конусе, власть и влияние земств возрастали по мере приближения к источнику доходов, а именно - к казне.

Таким образом, самостоятельность земских самоуправлений в рамках белой административной системы оказалась резко ограничена. Несмотря на периодическую критику власти, земства были зависимы от Северного правительства и в финансовом, и в политическом отношении. Более того, архангельские земцы осознавали, что система самоуправлений существует, лишь пока существует антибольшевистская Северная область и что приход большевиков сулит многим из них не только конец общественной карьеры, но политические преследования. Именно поэтому, несмотря на упреки в адрес кабинета, земцы продолжали его поддерживать. Не удивительно, что крах земской системы в Северной области произошел одновременно с падением белого правительства. 18 февраля 1920 г., когда развал белого фронта вынудил правительство принять решение об эвакуации, земские лидеры отказались взять управление губернией в свои руки. Спустя несколько дней Красная армия, не встретив сопротивления, вошла в Архангельск ${ }^{74}$. правительстве, см.: Polner, Russian Local Government during the War, 289.

73. ГААО, ф. 1865, оп. 1, д. 633, Материалы уездных земских собраний, 1919 г., л. 21 об.

74. Б.Ф. Соколов, «Падение Северной области», в И.В. Гессен, ред., Архив русской революции, т. 9 (Берлин: Слово, 1923), 64-65; С. Добровольский, «Борьба за возрождение России в Северной области», в Архив русской револющии, т. 3, 133-134, 137. 
Эпоха гражданской войны была противоречивым этапом в развитии земского самоуправления. С одной стороны, как показывает пример Северной области, земства смогли сравнительно быстро восстановить свою структуру и действовали довольно эффективно, опираясь на поддержку власти и сочувствие со стороны населения. Земства отчасти продолжали содействовать общественной интеграции, выявляя и доводя до сведения властей практические нужды жителей губернии. С другой стороны, в годы гражданской войны резко сократилась степень их политической и финансовой самостоятельности. Хотя в Северной области земские самоуправления при поддержке Чайковского получили большое влияние и широкий круг полномочий, даже в этом регионе они утратили свою автономию. Действуя в кризисных условиях военного противостояния, активно участвуя в мобилизации скудных людских и материальных ресурсов для нужд войны, а также находясь практически в полной финансовой зависимости от казны, северные земства значительно больше, чем дореволюционные земские учреждения, оказались связаны с государственной администрацией. По сути, они превратились в выборную часть государственной бюрократии, в местные распределительно-мобилизационные ответвления государственного аппарата. Единственным отличием их от других органов белой администрации было то, что земские руководители по-прежнему избирались населением, а не назначались сверху.

Огосударствление земств происходило не только под давлением кризисных обстоятельств, но и вследствие этатистских идейных представлений белых политиков и земских деятелей. Многие земцы стремились защитить российскую государственность, как от большевиков, так и от «анархических» масс, которые допустили разрушение послефевральского демократического порядка. В таких условиях земства, по их убеждению, должны были не столько выражать интересы населения, сколько воспитывать народные массы в духе государственности и патриотизма. Северные земства прилагали все усилия, чтобы мобилизовать население и ресурсы области на борьбу с большевиками и тесно сотрудничали с правительством, побуждая - а если надо и понуждая - население на более активную войну с большевиками.

Наконец, централизация земств, очевидно, отражала и общую политическую динамику гражданской войны, которая привела к сокращению автономии местной власти в целом. В условиях, когда само существование местных органов самоуправления зависело от устойчивости противоборствующих режимов, земства оказались подчинены северному белому правительству точно так же, как и советы стали частью единого советско-партийного аппарата ${ }^{75}$.

75. О влиянии гражданской войны на процессы, происходившие в советском тылу, в частности милитаризацию и централизацию большевистской партии и советской политической системы, см., в частности: Vladimir N. Brovkin, Behind the Front Lines of the Civil War: Political Parties and Social Movements in Russia, 1918-1922 (Princeton: Princeton University, 1994). Автор также справедливо отметил образовавшийся раскол между лидерами всех политических партий и массами в годы гражданской войны. 
И лишь после крушения белых режимов земства смогли эмансипироваться от опеки власти и, наконец, превратились в защитников интересов представляемых ими общин. Многие члены земских организаций, успевшие эвакуироваться из России, нашли приют в заграничных земских комитетах. Последние были созданы в центрах эмигрантского рассеяния, и именно их гуманитарные усилия помогли тысячам русских беженцев приспособиться к жизни в изгнании ${ }^{76}$.

Национальный исследовательский университет «Высшая школа экономики» Международный изентр истории и соичиологии

Второй мировой войны и ее последствий

lnovikova@hse.ru russes et le Zemgor (1921-1930)», 46, 4 (2005): 667-850. 